Acta Bot. Croat. 70 (1), 9-21, 2011

CODEN: ABCRA 25

ISSN 0365-0588

eISSN 1847-8476

DOI: $10.2478 / \mathrm{v} 10184-010-0013-6$

\title{
Early post-fire changes in Pinus brutia forests (Amanos Mountains, Turkey)
}

\author{
NeCATTIN TÜRKMEN*, ATABAy DÜZENLI \\ Department of Biology. Faculty of Science and Letters. Çukurova University, 01330 \\ Adana, Turkey
}

We studied the species composition and soil nutrients in a Pinus brutia forest after a fire that occurred in 1989. Four permanent plots were created in the burnt and not burnt areas in the Amanos Mountains of Turkey. The floristic richness, biological spectra, above ground phytomass and soil features in the study areas were assessed during the first three years after the fire. After the fire, we found a reduced amount of organic matter (14.3\%), total nitrogen $(22 \%)$ and soil water saturation $(13.1 \%)$, but an increased amount of available phosphorus $(71 \%)$, acidity (3.6\%), cation exchange capacity $(9.9 \%)$, exchangeable sodium $(20.8 \%)$ and exchangeable potassium $(37.1 \%)$. The aboveground phytomass in the burned area reached $5284 \mathrm{~kg} \mathrm{ha}^{-1}$, the third year after the fire. Forty-six pre-fire species were renewed in the first three years after the fire. Juniperus oxycedrus could not renew within three years after the fire. Pine phytomass has increased five times within three years after the fire.

Key words: Forest, fire, Pinus brutia, succession, soil

\section{Introduction}

Fire is one of the most important ecological factors in Mediterranean-type ecosystems. Most Mediterranean-type vegetation is composed of woodland in various degradation stages created by the long history of human activities (LE HoureOu 1974, NAVEH 1990, Trabaud 2000, BiLgiLI and SAĞLAM 2003). Depending on their post-fire reaction, plant species are classified as »seeders «, »sprouters «, or both types. Pine forest communities are very flammable during drought periods as they contain rich resins, essential oils, litter and understory shrub layers. On the other hand, these are resistant to fire in the absence of human pressures such as grazing, cutting and cultivation (MAZZOLENI and EsPosito 1993, NE'EMAN et al. 2004).

* Corresponding author, e-mail: nturkmen@cu.edu.tr

Copyright $^{\circledR} 2011$ by Acta Botanica Croatica, the Faculty of Science, University of Zagreb.

All rights reserved. 
Pinus brutia Ten. covers extensive areas in the Eastern Mediterranean: mainly Turkey, Greece, Cyprus, W. Syria, Lebanon and Italy; scantly N. Iraq, W. Caucasus and Crimea (GEZER 1986, FADY et al. 2003) (Fig. 1). The total P. brutia forest cover is estimated to be over 4 million hectares, 3.8 million hectares of which are in Turkey, accounting for $20.2 \%$ of Turkey's total forest area. Of this, 2.2 million hectares are productive while 1.6 million hectares are degraded. Economically, it is Turkey's most important forest tree species (DAVIS 1965-1985, FADY et al. 2003, BOYDAK 2004).

Fires are started for reasons like acquiring new grazing land, clearing for new farmland, smoking, arson, camping, glass waste and various accidents with $99 \%$ of the forest fires in Turkey being caused by humans; with only ca $1 \%$ of the recorded forest fires being started by lightning. The origin of about half the human-caused fires is shown to be negligence $(25 \%)$ and deliberate fire-setting (26\%). It is assumed that most of the fires with unknown origins are intentionally set fires, including arson (SEREZ 1995).

Forty-eight percent (9732 840 ha) of the forests in Turkey are susceptible to fire due to the Mediterranean climate (TÜRKMEN and DÜZENLİ 2005), and the flammable and combus-

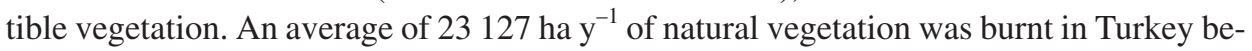
tween 1937-2003 with 72316 fires occurring and 1549506 ha of forest being burnt.

The post-fire succession in pine forests has not previously been studied in Turkey, although some studies on this subject were conducted in other countries with Mediterranean type ecosystems such as France (Trabaud 2000), Greece (Arianoutsou-FaragGitaki 1984, Thanos et al. 1989), Italy (MAZzoleni and Esposito 1993), Spain (FARACo et al. 1993), the United States (HANES 1970, KEELEY 1987) and Israel (NAVEH 1975). The aim of the present study is therefore to examine the effects of fire on the soil properties and the floristic diversity of Pinus brutia forests in Turkey, from the immediate post-fire period up to three years after the fire.

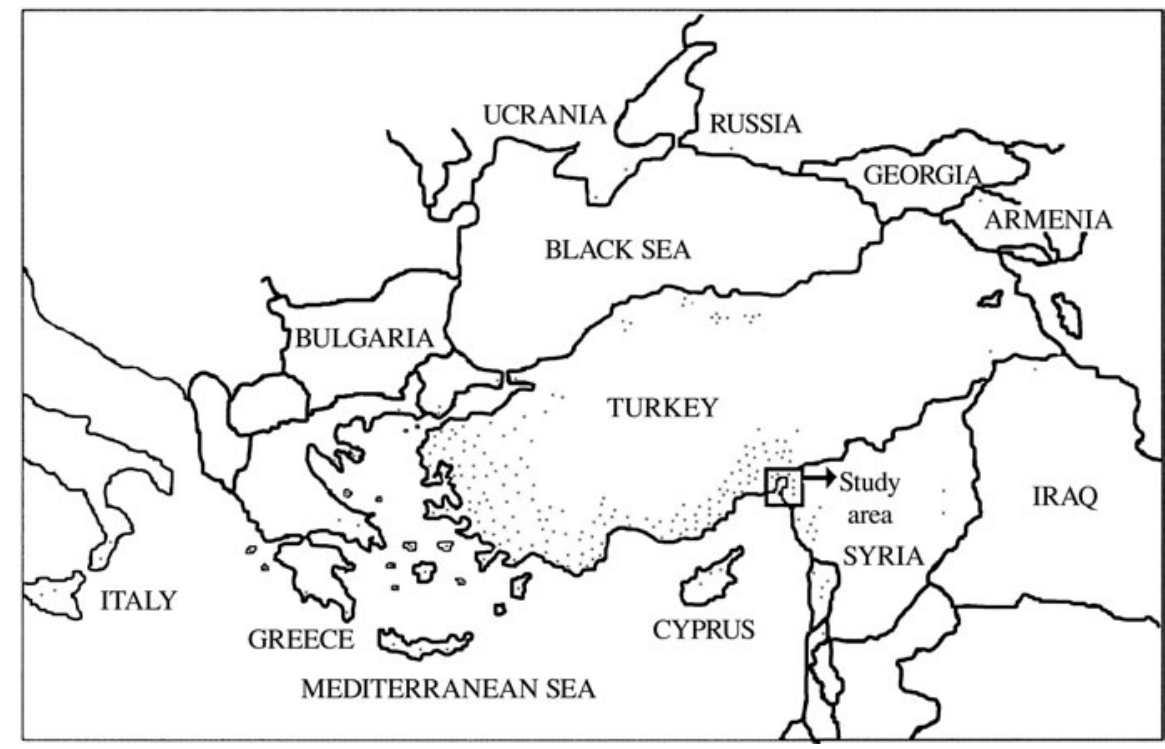

Fig. 1. Study area and distribution of Pinus brutia woods $(\bullet)$. 


\section{Study area}

The study area is located on a hillside near Erzin town ( $36^{\circ} 57^{\prime}$ N. $\left.36^{\circ} 16^{\prime} \mathrm{E}\right)$, Hatay Province, Turkey, ca. $550 \mathrm{~m}$ above sea level and $14 \mathrm{~km}$ from the İskenderun Gulf (Fig. 1).

\section{Climate}

The Mediterranean climate in the study area is characterized by long summer droughts and mild and rainy winters. The mean annual precipitation is about $1019.3 \mathrm{~mm}$, while the monthly precipitation is approximately $22.4 \mathrm{~mm}$ in July and $130.3 \mathrm{~mm}$ in January. The mean maximum temperatures range from $15.2^{\circ} \mathrm{C}$ in January to $32.2{ }^{\circ} \mathrm{C}$ in August and the mean minimum temperatures from $6.8^{\circ} \mathrm{C}$ in January to $23.8^{\circ} \mathrm{C}$ in August. The bioclimatic diagram prepared for the study area shows the months with dry and rainy periods (Fig. 2).

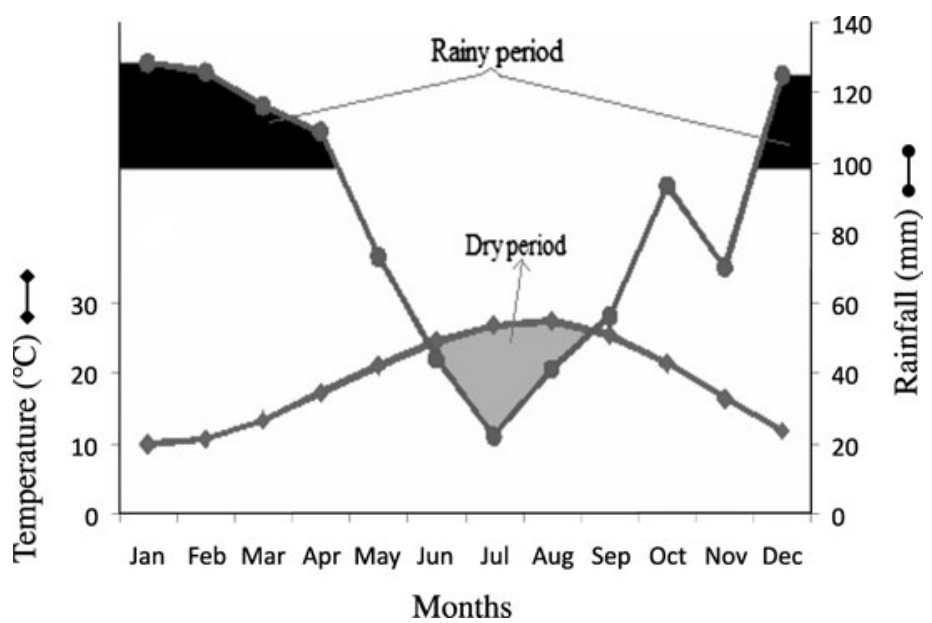

Fig. 2. Ombrothermic diagram of the study area. The dry period in July - August, the rainy period ( $>100 \mathrm{~mm} / \mathrm{month}$ in December - April, and transitional period in May and November.

\section{Geology}

The geological structure of the area is of Mesozoic and Cretaceous limestone, Upper Cretaceous ultra-basic rocks (gabro and serpentine) and Tertiary marls. The common soil formation distinguished in the area is brown forest soils (TÜRKMEN and DÜZENLI 1998).

\section{Vegetation}

The native woody vegetation of the study area is mainly composed of Pinus brutia Ten., Quercus cerris L., Styrax officinalis L.. Fraxinus ornus L.. Cotinus coggyrea Scop.. Pistacia terebinthus L.. Cistus salviifolius L.. Cercis siliquastrum L.. Erica manipuliflora Salisb.. Sorbus torminalis (L.) Crantz. Genista lydia Boiss. and Smilax aspera L.. A part of the Pinus brutia vegetation in the Amanos Mountains under the responsibility of the Dörtyol Forestry Administration of Hatay Province in Turkey was intensely burnt at the end of February 1989 as a result of negligence by a shepherd. 


\section{Materials and methods}

In order to analyze the changes in species composition, soil elements, above ground phytomass and physiognomy of the plant community in this area, four permanent plots were established in the burned area and four in the adjacent unburned area. The unburned plots are the control plots. Each plot was $100 \mathrm{~m}^{2}(10 \mathrm{~m} \times 10 \mathrm{~m})$. Both burned and unburned plots were evaluated as single plots. All floristic records were made monthly from February 1989 to February 1992. In each of the burned plots, four sub-plots $(2 \mathrm{~m} \times 2 \mathrm{~m})$ were randomly created for post-fire plant biomass determination. All the vascular plants in subplots were cut with hand equipments (with bucksaw, hatchet and prune scissors) as close to the soil surface as possible.

To determine phytomass, the harvested material was air dried in an oven at $105^{\circ} \mathrm{C}$. Five robust suckers from each woody species were cut, dried in the oven and weighted.

In total, 24 soil samples from the study plots were taken ( 24 of these samples from burned plots. and 4 from unburned plots). Each soil sample was created by mixing the upper soil layer (0-15 cm as depth) in the center of the corner of each plot. These soil samples were dried in the open air, and after being sieved in a fine sieve in the laboratory were analyzed using relevant methods. Air-dry sieved soil samples were analyzed in the Department of Soil Sciences, Çukurova University.

The soil analysis was performed according to BAYRAKLI (1987). Lime $\left(\mathrm{CaCO}_{3}\right)$ was determined with a Scheibler calcimeter measuring the carbon dioxide pressure. Organic carbon was determined by Walkley-Black wet oxidation method, total nitrate by the semi-micro Kjeldahl method. Available phosphorus $\left(\mathrm{P}_{2} \mathrm{O}_{5} \mathrm{~kg} \mathrm{ha}^{-1}\right)$ was determined according to Olsen et al. (1954) (using phosphorus solubility in sodium bicarbonate). Exchangeable sodium (expressed as $\mathrm{cmol}_{\mathrm{c}} \mathrm{kg}^{-1}$, i.e. centimoles of charge per kilogram of dry soil) was determined by $1 \mathrm{~N}$ ammonium acetate, exchangeable potassium $\left(\mathrm{cmol}_{\mathrm{c}} \mathrm{kg}^{-1}\right)$ by $1 \mathrm{~N} \mathrm{ammo-}$ nium acetate. Total salt was determined by electrical conductivity within the $100 \mathrm{~g}$ water-saturated soil. For cation exchange capacity $\left(\mathrm{cmol}_{\mathrm{c}} \mathrm{kg}^{-1}\right) 1 \mathrm{~N}$ sodium acetate-soil mixture was washed with $2 \mathrm{~N}$ ammonium acetate. Acidity $(\mathrm{pH})$ was determined using distilled water-saturated soil samples, after waiting 24 hours, using a Beckman pH meter connected to a glass-calomel electrode pair. Soil water saturation (\%) was determined by measuring the amount of saturated pure water of $100 \mathrm{~g}$ air-dried soil.

Sorensen's similarity index (SI) was used to compare the species diversity of the burned and unburned areas:

$$
\mathrm{SI}=2 \mathrm{w} /(\mathrm{a}+\mathrm{b})
$$

where $\mathrm{a}$ is the total number of species in sample $1, \mathrm{~b}$ is the number of species in sample 2 and $w$ is the number of species common to both samples.

The collected plant material was numbered and kept as samples for botanical identification. Taxonomical determination was performed according to DAVIS (1965-1985). A voucher specimens of each species was kept in the Herbarium of Çukurova University, Faculty of Science and Letters, Department of Biology. 


\section{Results}

The flora of the unburned area $\left(400 \mathrm{~m}^{2}\right)$ consisted of 47 resident species and floristically it did not change during the three years after the fire. In the burned area $\left(400 \mathrm{~m}^{2}\right)$, the presence of plant species that changed throughout the observation period is as follows: 26 species (24 autochthonous specific for the brutia pine community, and 2 allochthonous or exotic for the brutia pine community in the first year; 55 species ( 39 autochthonous and 16 allochthonous) in the second year; and 66 species (46 autochthonous and 20 allochthonous) in the third year (Tab. 1).

Ninety-eight percent of the pre-fire species (i.e. 46 species) occurred in the first three years after the fire, while the remaining $2 \%$ (i.e. 1 species) did not occur during this time. The floristic richness of the burnt community showed a tendency that resembles the stabile balance that existed before the fire (Fig. 3, Tab. 2).

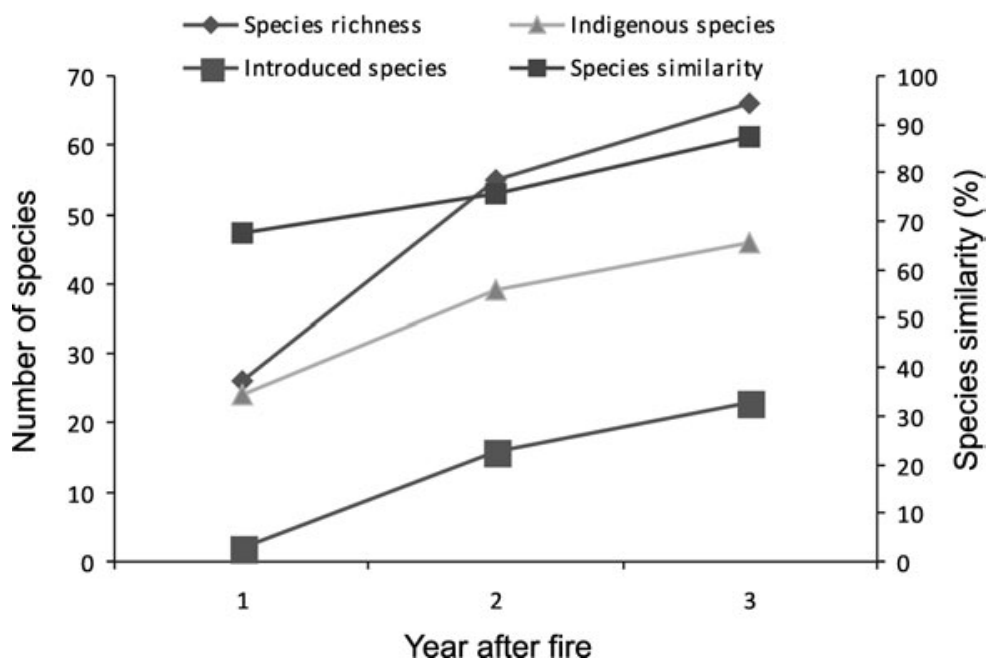

Fig. 3. Development and floristic composition after the fire.

The phytomass above ground of the burnt vegetation reached $5283.8 \mathrm{~kg} \mathrm{ha}^{-1}$ (herbaceous phytomass $2845.9 \mathrm{~kg} \mathrm{ha}^{-1}$, woody phytomass $2437.9 \mathrm{~kg} \mathrm{ha}^{-1}$ ) showing rapid growth at the end of third year. Phytomass of the pine seedlings were much lower $(9.9 \mathrm{~g}$ per 5 seedlings) than a woody resprouter species (e.g., phytomass of oak species is 401 times greater than that of pine species) due to both the pine species being an obligate seeder and woody resprouter species being capable of vigorous re-growth with spare nutrients (Tabs. 3, 4). The first three years, root growth of the pine was faster than stem growth (the root length was $18.3 \mathrm{~cm}$ in second year and $29.6 \mathrm{~cm}$ in third year while the stem length was $7.1 \mathrm{~cm}$ and $19.8 \mathrm{~cm}$ respectively).

The soil analysis in the study area (Fig. 4) indicated that immediately after the fire organic C (\%)decreased from 13.37 to 11.46 , later was reduced to 5.14. Total N (\%) immediately after the fire decreased from 0.391 to 0.305 , and then later was reduced to 0.217 . Soil water saturation immediately after the fire decreased from 103.2 to 89.7 , later was reduced 
Tab. 1. Occurrence of the plant species in the study area. $\mathbf{L F}$ denotes life form: $\mathbf{T h}-$ terophyte, $\mathbf{G e}-$ geophytes, $\mathbf{H}$ - hemicryptophyte, $\mathbf{P h}$ - phanerophyte, $\mathbf{C h}$ - chamaeophyte. $\mathbf{L}$ denotes life span: A - annual, B - biannual, $\mathbf{P}$ - perennial. RS denotes reproductive strategy: $\mathbf{G}$ - generative, $\mathbf{V}$ - vegetative, VG - both generative and vegetative. Presence of species in terms of time after fire: $\mathbf{m}$ - first three mounts, $\mathbf{1}$ - first year, $\mathbf{2}$ - second year, $\mathbf{3}$ - third year. - denotes absence, + denotes presence.

Species

Family

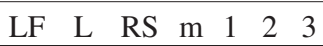

\section{Autochthonous species}

Alyssum strigosum Banks et Sol. ssp. strigosum

T. R. Dudley

Asparagus acutifolius $\mathrm{L}$.

Asperula cymulosa (Post) Post

Asperula stricta Boiss. ssp. stricta Ehrend. et

Schönb.-Tem.

Asplenium adiantum-nigrum $\mathrm{L}$.

Brachypodium pinnatum (L.) P. Beauv.

Centaurea ptosimopappa Hayek

Cercis siliquastrum L. ssp. hebacarpa (Bornm.) Yalt.

Brassicaceae

Th A G - - +

Chrysopogon gryllus (L.) Trin.

Cistus salviifolius L.

Clinopodium vulgare L. ssp. arundanum (Boiss.) Nyman

Cotinus coggyrea Scop.

Crepis reuterana Boiss.

Cytisopsis dorycniifolia Jaub. et Spach ssp.

dorycniifolia D.F.Chamb.

Dactylis glomerata L. ssp. hispanica (Roth) Nyman

Dorycnium graecum (L.) Ser.

Epipactis helleborina (L.) Crantz

Erica manipuliflora Salisb.

Eryngium falcatum Delar

Euphorbia apios L. var. lamprocarpa Boiss.

Euphorbia macrostegia Boiss.

Ferulago cassia Boiss.

Fraxinus ornus L. ssp. cilicica (Lingelsh.) Yalt.

Genista lydia Boiss. var. antiochia (Boiss.) P. Gibbs.

Gladiolus italicus Miller

Hedera helix $\mathrm{L}$.

Iris unguicularis Poiret

Juniperus oxycedrus L. ssp. oxycedrus Coode et Cullen

Lesquereuxia syriaca Boiss. et Reut.

Melica minuta L.

Muscari tenuiflorum Tausch

Origanum laevigatum Boiss.
Liliaceae

Rubiaceae

Rubiaceae

Ge $\mathrm{P} \quad \mathrm{G}-\ldots+$

Ch $\mathrm{P}$ VG $-\ldots++$

Ch $\mathrm{P}$ VG $-\ldots++$

Aspleniaceae

Poaceae

Asteraceae

Fabaceae

Poaceae

Cistaceae

Lamiaceae

Fabaceae

Asteraceae

Fabaceae

Poaceae

Fabaceae

Orchidaceae

Ericaceae

Apiaceae

Euphorbiaceae

Euphorbiaceae

Apiaceae

Oleaceae

Fabaceae

Iridaceae

Araliaceae

Iridaceae

Cupressaceae

Scrophullariaceae

Poaceae

Liliaceae

Lamiaceae $\begin{array}{lllll} & \mathrm{H} & \mathrm{P} & \mathrm{G} & -\end{array}$

$\begin{array}{llll}\mathrm{H} & \mathrm{P} & \mathrm{V} & +++\end{array}$

$\mathrm{H} \quad \mathrm{P} \quad \mathrm{G}++++$

$\mathrm{Ph} \mathrm{P} \quad \mathrm{V}++++$

H $\quad \mathrm{P} \quad \mathrm{V}++++$

Ch $\mathrm{P} \mathrm{G}++++$

Ch $\mathrm{P}$ VG $-\ldots++$

$\mathrm{Ph} \mathrm{P} \quad \mathrm{V}++++$

$\mathrm{H} \quad \mathrm{P} \quad \mathrm{G}++++$

Ch $\mathrm{P}$ G $-\quad+$

$\mathrm{H} \quad \mathrm{P} \quad \mathrm{V}++++$

Ch $\mathrm{P}$ VG $-{ }_{-}+$

Ge $\mathrm{P}$ VG ++++

$\mathrm{Ph} \mathrm{P} \quad \mathrm{VG}++++$

$\mathrm{H} \quad \mathrm{P} \quad \mathrm{VG}++++$

Ge $\mathrm{P} \quad \mathrm{V}-{ }_{-}+$

H $\quad \mathrm{P} \quad \mathrm{G}-+++$

H $\quad \mathrm{P} \quad \mathrm{G} \quad-\ldots+$

$\mathrm{Ph} \mathrm{P} \quad \mathrm{V}+++$

Ch $\mathrm{P} V G++++$

Ge $\mathrm{P}$ VG $-{ }_{-}+$

Ch $\mathrm{P}$ V $-\ldots+$

Ge $\mathrm{P}$ VG $-\ldots++$

$\mathrm{Ph} \quad \mathrm{P} \quad \mathrm{G}-{ }_{-}$

$\mathrm{H} \quad \mathrm{P} \quad \mathrm{VG}--++$

$\mathrm{H} \quad \mathrm{P} \quad \mathrm{V}++++$

Ge $\mathrm{P}$ VG $-\ldots++$

Ch $\mathrm{P}$ VG -+++ 
Tab. 1. - continued

\begin{tabular}{|c|c|c|c|c|c|c|c|c|}
\hline Species & Family & LF & $\mathrm{L}$ & RS & $\mathrm{m}$ & 1 & 2 & 3 \\
\hline Osyris alba $\mathrm{L}$. & Santalaceae & $\mathrm{Ch}$ & $\mathrm{P}$ & G & - & - & & + \\
\hline Pinus brutia Ten. & Pinaceae & $\mathrm{Ph}$ & $\mathrm{P}$ & G & - & - & & + \\
\hline Pistacia terebinthus L. ssp. palaestina (Boiss.) Engl. & Anacardiaceae & $\mathrm{Ph}$ & $\mathrm{P}$ & V & + & + & & + \\
\hline Potentilla micrantha Ramond ex DC. & Rosaceae & $\mathrm{H}$ & $\mathrm{P}$ & G & - & - & & + \\
\hline Quercus cerris L. var. cerris Hedge et Yalt. & Fagaceae & $\mathrm{Ph}$ & $\mathrm{P}$ & V & + & + & + & + \\
\hline $\begin{array}{l}\text { Quercus infectoria Oliv. ssp. boissieri (Reut.) } \\
\text { O.Shwarz }\end{array}$ & Fagaceae & $\mathrm{Ph}$ & $\mathrm{P}$ & $\mathrm{V}$ & - & - & & + \\
\hline $\begin{array}{l}\text { Rubus canescens DC. var. glabratus (Godr.) Davis } \\
\text { et Meikle }\end{array}$ & Rosaceae & $\mathrm{Ch}$ & $\mathrm{P}$ & $\mathrm{V}$ & + & + & & + \\
\hline Ruscus aculeatus L. var. angustifolius Boiss. & Liliaceae & $\mathrm{Ch}$ & $\mathrm{P}$ & $\mathrm{V}$ & - & + & & + \\
\hline Saccharum strictum(Host) Sprengel & Poaceae & $\mathrm{H}$ & $\mathrm{P}$ & VG & + & + & + & + \\
\hline Salvia tomentosa $\mathrm{L}$. & Lamiaceae & $\mathrm{H}$ & $\mathrm{P}$ & $\mathrm{G}$ & - & - & + & + \\
\hline Smilax aspera $\mathrm{L}$. & Liliaceae & $\mathrm{Ph}$ & $\mathrm{P}$ & VG & + & + & + & + \\
\hline Sorbus torminalis (L.) Crantz var. torminalis Gabrieljan & Rosaceae & $\mathrm{Ph}$ & $\mathrm{P}$ & VG & + & + & + & + \\
\hline Stachys diversifolia Boiss. & Lamiaceae & $\mathrm{Ch}$ & $\mathrm{P}$ & VG & - & - & + & + \\
\hline lparStyrax officinalis L. & Styracaceae & $\mathrm{Ph}$ & $\mathrm{P}$ & $\mathrm{V}$ & + & + & + & + \\
\hline Viola alba Besser ssp. dehnhardtii (Ten.) Becker & Violaceae & $\mathrm{H}$ & $\mathrm{P}$ & G & - & - & - & + \\
\hline \multicolumn{9}{|l|}{ Allochthonous species } \\
\hline Carex flacca Schreber ssp. serrulata (Biv.) Greuter & Cyperaceae & $\mathrm{H}$ & $\mathrm{P}$ & G & - & - & - & + \\
\hline Cephalaria taurica Szabo & Scrophullariaceae & $\mathrm{H}$ & $\mathrm{P}$ & G & - & - & + & + \\
\hline Chenopodium album L. ssp. album & Chenopodiaceae & Th & A & G & - & - & - & + \\
\hline Conyza bonariensis(L.) Cronquist & Asteraceae & $\mathrm{Th}$ & A & G & - & - & + & + \\
\hline $\begin{array}{l}\text { Dorycnium penthaphyllum Scop. ssp. haussknetchii } \\
\text { (Boiss.) Gams }\end{array}$ & Fabaceae & $\mathrm{Ch}$ & $\mathrm{P}$ & G & - & - & + & + \\
\hline Hypericum montbretii Spach & Hypericaceae & $\mathrm{Th}$ & A & G & - & - & - & + \\
\hline Inula vulgaris(Lam.) Trevis. & Asteraceae & $\mathrm{H}$ & B & G & - & - & + & + \\
\hline Lactuca serriola $\mathrm{L}$. & Asteraceae & $\mathrm{H}$ & B & G & - & - & + & + \\
\hline Lathyrus spathulatus Cel. & Fabaceae & $\mathrm{H}$ & $\mathrm{P}$ & G & - & - & + & + \\
\hline Lotus peregrinus L. var. peregrinus Heyn & Fabaceae & $\mathrm{Th}$ & A & G & - & - & - & + \\
\hline Michauxia campanuloides L'Her. ex Aiton & Campanulaceae & $\mathrm{H}$ & B & G & - & - & - & + \\
\hline Orobanche crenata Forssk. & Orobanchaceae & $\mathrm{Th}$ & A & G & - & - & + & + \\
\hline Pterdium aquilinum (L.) Kuhn & Hypolepidaceae & $\mathrm{Ge}$ & $\mathrm{P}$ & G & + & + & + & + \\
\hline Rhus coriaria $\mathrm{L}$. & Anacardiaceae & $\mathrm{Ph}$ & $\mathrm{P}$ & G & - & - & - & + \\
\hline Senecio vernalis Waldst. et Kit. & Asteraceae & $\mathrm{Th}$ & A & G & - & - & + & + \\
\hline Sideritis perfoliata $\mathrm{L}$. var. condensata Boiss. & Lamiaceae & $\mathrm{H}$ & $\mathrm{P}$ & G & - & + & + & - \\
\hline Silene confertifolia Chowdh. & Caryophyllaceae & $\mathrm{H}$ & $\mathrm{P}$ & G & - & - & + & + \\
\hline Sonchus oleraecus L. & Asteraceae & Th & A & G & - & - & + & - \\
\hline Thesium bergeri Zucc. & Santalaceae & $\mathrm{Ch}$ & $\mathrm{P}$ & G & - & - & + & + \\
\hline Thlaspi annuum Koch & Brassicaceae & $\mathrm{Th}$ & A & G & - & - & + & + \\
\hline Torilis arvensis (Huds.) Link ssp. arvensis Cullen & Brassicaceae & $\mathrm{Th}$ & A & G & - & - & + & + \\
\hline Trifolium campestre Schreb. & Fabaceae & $\mathrm{Th}$ & A & G & - & - & + & \\
\hline Verbascum galileum Boiss. & Scrophulariaceae & $\mathrm{H}$ & $\mathrm{B}$ & G & - & - & & + \\
\hline
\end{tabular}


Srečec S., Zechner-Krpan V., Marag S., Špoljarić I., Kvaternjak I., MrŠIĆ G.

Tab. 2. Relative contribution of autochthonous and allochthonous species at the burnt site, and the species similarity between burned and unburned areas after fire.

\begin{tabular}{lccc}
\hline $\begin{array}{l}\text { Time afterthe } \\
\text { fire }\end{array}$ & $\begin{array}{c}\text { Number of autochthonous } \\
\text { species (and relative } \\
\text { contribution) }\end{array}$ & $\begin{array}{c}\text { Number of allochthonous } \\
\text { species (and relative } \\
\text { contribution) }\end{array}$ & $\begin{array}{c}\text { Sorensen similarity } \\
\text { index (\%) }\end{array}$ \\
\hline 1 year & $24(51.1)$ & $2(8.7)$ & 67.5 \\
2 years & $15(31.9)$ & $14(60.9)$ & 76.4 \\
3 years & $7(14.9)$ & $7(30.4)$ & 81.4 \\
\hline Total & $47(97.9)$ & $23(100)$ & - \\
\hline
\end{tabular}

Tab. 3. Characteristics of the plant species appearing in the first three years after fire (pine seedlings did not occur within the first year; to avoid damage to the vegetation. the biomass of the second year was not determined).

\begin{tabular}{lccc}
\hline Characteristics & First year & Second year & Third year \\
\hline Pine seedlings: & - & 7.1 & 19.8 \\
Height (cm) & - & & \\
Root lenght (cm) & - & 18.3 & 29.6 \\
Stem phytomass (g per 5 suckers) & - & 1.1 & 5.2 \\
Needle phytomass (g per 5 suckers) & - & 0.7 & 3.1 \\
Root phytomass (g per 5 suckers) & - & 0.3 & 1.2 \\
Total pine phytomass (g per 5 suckers) & 162 & 2.2 & 9.9 \\
Vegetation biomass (kg per ha): & & - & 5283.2 \\
\hline
\end{tabular}

Tab. 4. Height and phytomass values of dominant understory woody species of the pine forest in the third year.

\begin{tabular}{lcccc}
\hline Species & $\begin{array}{c}\text { Woody } \\
\text { (g of 5 suckers) }\end{array}$ & $\begin{array}{c}\text { Herbaceous } \\
\text { (g of 5 suckers) }\end{array}$ & $\begin{array}{c}\text { Total } \\
\text { (g of 5 suckers) }\end{array}$ & $\begin{array}{c}\text { Max. heights } \\
\text { (cm) }\end{array}$ \\
\hline Quercus cerris & 2455 & 849 & 3304 & 391 \\
Styrax officinalis & 1636 & 272 & 1908 & 305 \\
Pistacia terebinthus & 923 & 311 & 1235 & 171 \\
Fraxinus ornus & 947 & 106 & 1052 & 226 \\
Cercis siliquastrum & 619 & 250 & 869 & 230 \\
Cotinus coggyrea & 525 & 210 & 736 & 198 \\
Cistus salviifolius & 213 & 76 & 289 & 82 \\
Sorbus torminalis & 94 & 57 & 151 & 30 \\
Erica manipuliflora & 44 & 19 & 63 & 38 \\
\hline
\end{tabular}


POST-FIRE CHANGES IN THE PINUS BRUTIA FORESTS
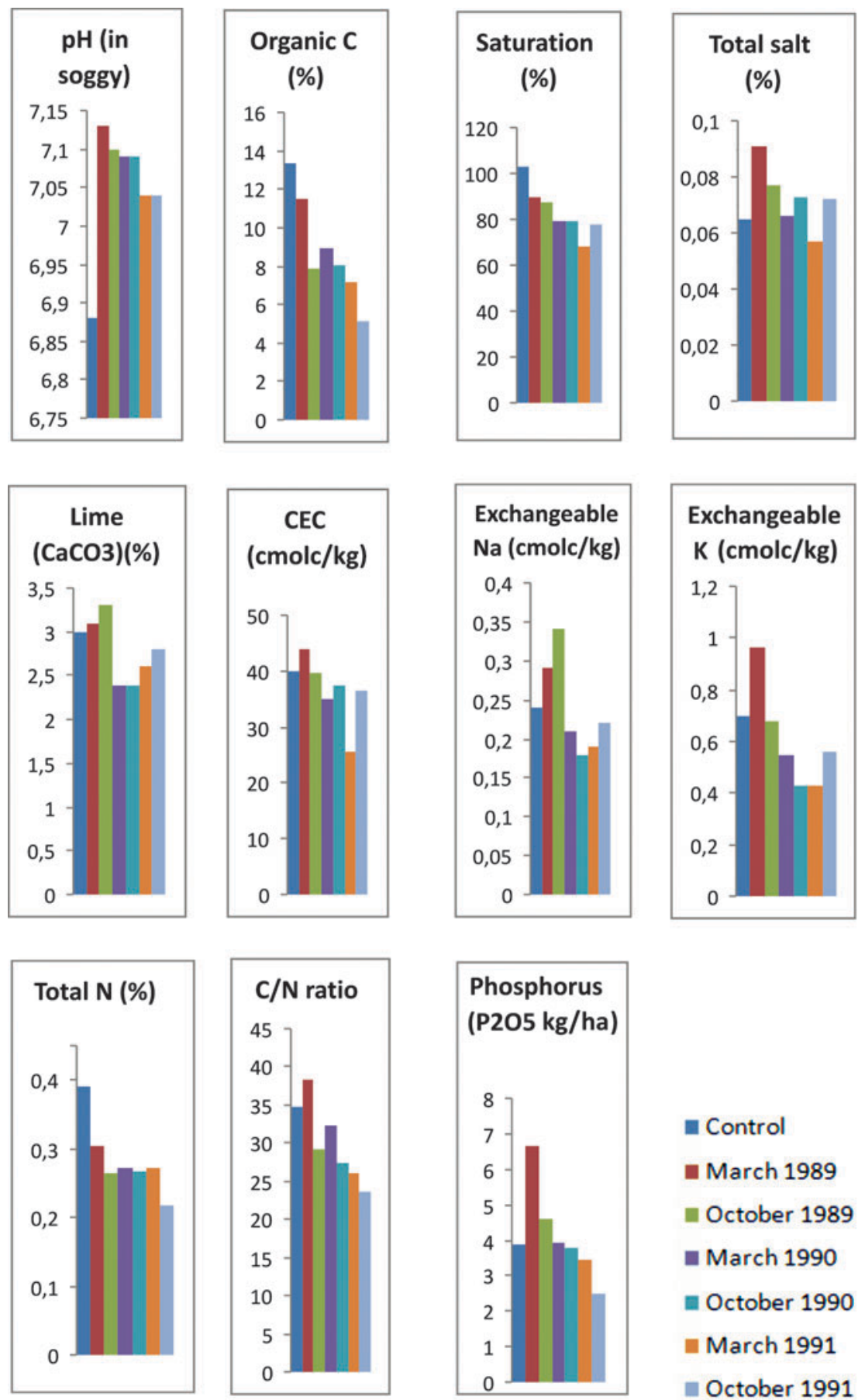

Fig. 4. Changes of soil ph, organic carbon content, water saturation, contribution of coluble salt, lime $\left(\mathrm{CaCO}_{3}\right)$, cation exchange capacity $(\mathrm{CEC})$, exchangeable $\mathrm{Na}$, exchangeable $\mathrm{K}$, total nitrogen, $\mathrm{C} / \mathrm{N}$ ratio, and available phosphorus $\left(\mathrm{P}_{2} \mathrm{O}_{5}\right)$ after the fire. 
to 77.9. $\mathrm{C} / \mathrm{N}$ ratio immediately after the fire increased from 34.83 to 38.27 , later was reduced to 23.55. Available phosphorus $\left(\mathrm{P}_{2} \mathrm{O}_{5} \mathrm{~kg} \mathrm{ha}^{-1}\right)$ immediately after the fire increased from 0.390 to 0.667 , later was reduced to $0.250 ; \mathrm{pH}$ value (in soggy soil) immediately after the fire increased from 6.88 to 7.13 , later was reduced to $7.04 \mathrm{cmol}_{\mathrm{c}} \mathrm{kg}^{-1}$; exchangeable $\mathrm{K}$. immediately after the fire increased from 0.70 to 0.96 , later was reduced to $0.56 \mathrm{cmol}_{\mathrm{c}} \mathrm{kg}^{-1}$; exchangeable $\mathrm{Na}$ immediately after the fire increased from 0.24 to 0.29 , later was reduced to $0.22 \mathrm{cmol}_{\mathrm{c}} \mathrm{kg}^{-1}$; cation exchange capacity immediately after the fire increased from 39.86 to 43.80 , later was reduced to $36.45 \mathrm{cmol}_{\mathrm{c}} \mathrm{kg}^{-1}$; lime $\left(\mathrm{CaCO}_{3}\right)$ immediately after the fire increased from 3.0 to 3.1, later was reduced to $2.8 \%$; total salt immediately after the fire increased from 0.665 to 0.091 , later was reduced to $0.072 \%$. Similar trends were found in the earlier studies, elsewhere (AHLgRen and AHLgRen 1960, RAison 1979, Kutiel and SHAVIV 1989).

\section{Discussion}

All the existing species before the fire (species at the control site), except for Juniperus oxycedrus L., emerged again within the first three years after the fire. Juniperus oxycedrus did not resprout from the lignotubers or burls. The new habitat conditions created by fire led to the emergence of allochthonous opportunistic species such as Sonchus olereacus, Sideritis perfoliata, Senecio vernalis, Trifolium campestre, Conyza bonariensis, Lactuca serriola and Verbascum galileum. These species caused an increase in the floristic richness of the area in the first three years (the richness includes both native and non-native species) but an elimination started by the dominance of the autochthonous sprouting phanerophytes. The most typical sprouter phanerophytes were Quercus cerris. Fraxinus ornus. Cotinus coggyrea. Pistacia terebinthus and Erica manipuliflora which can vigorously regenerate by root sprouting. The woody species that reproduce by seedlings only were Pinus brutia and Cistus salviifolius. These two woody species are known pyrophytes because of better germination and growth show in burned areas. The re-sprouting species remained alive in the fire, stored food reserves are developed by sprouting from vegetative organs. Many herbaceous re-sprouters having subterranean root organs (rhizomes or tubers) such as Saccharum strictum, Brachypodium pinnatum, Dactylis glomerata and Epipactis helleborina regenerated easily in the first year after the fire. These results agreed with those presented by the other authors (DAubenMIRE 1968, TrabAud 1973, Verroius and GeORgiadis 2002, TÜRKMEN and DÜZENLI 2005).

The allochthonous species (species not seen in the control site occurred only from seeds in the burned areas. In the presence of autochthonous species, their seeds and / or vegetative organs were able to continue.

Subterranean organs are protected from fire by the soil, which is a good insulator and conducts little heat produced by the burning vegetation (ASTON and GILL 1976). Mooney and Dunn (1970) found that nearly $50 \%$ of the small woody shrubs in California and Chile sprouted after a fire. NAVEH (1975) in Israel, TRABAUd and LEPART (1980) in southern France, ThANOS et al. (1989) in Samos Island of Greece and TürKMEN and DüZENLI (2005) in the Turkish Mediterranean Region found that nearly all the woody species of these regions sprouted after a fire within 3-5 years.

The emergence of the original species was $51.1 \%$ in the first year, $31.9 \%$ in the second year and $14.7 \%$ in the third year. It is known that some Mediterranean ecosystems evolve 
with fire and that most plant species have developed adaptive mechanisms (TRABAUD 1987). These mechanisms could be associated with the strategies of persistence after a fire (e.g. species that regenerate well or disseminate numerous seeds after a fire).

Among the allochthonous species, the most prolific families were Asteraceae ( 5 species) and Fabaceae (4 species). The Fabaceae are of special interest due to their waterproof hard-coated seeds and ability to fix atmospheric nitrogen. These characteristics increased the germination abilities of their seeds in the soil seed bank after the fire. The diminished nitrogen in the burnt soils can be slightly resolved through the quick nitrogen fixation of the leguminous species. The dispersal abilities of the many species that belong to the Asteraceae are usually more than those in other families (VERroiUs and GEORGIADIS 2002). Most of these plants occur usually in open areas such as forest roadsides, forest-adjacent agricultural areas and abandoned fields and have small, light seeds with pappus-like structures. Therefore, it was observed that these families were more abundant during the study period than before the fire.

The pre-fire species were detected in early post-fire vegetation and species richness increased during the three years after the fire due to the high abundance of short-lived herbaceous plants, which benefit from enriched supply with nutrients and light, as has been explained before (BuHK et al. 2006).

\section{Acknowledgements}

We wish to thank the soil laboratory personnel of Çukurova University for their valuable help in making the soil analysis, the Çukurova University Research Fund (FBE-89-E 29) for their financial assistance, and the anonymous referees for their helpful comments.

\section{References}

Ahlgren. I., Ahlgren, C. E., 1960: Ecological effects of forest fires. The Botanical Review 26, 48-533.

Arianoutsou-Faraggitaki, M., 1984: Post-fire successional recovery of a phryganic (East Mediterranean) ecosystem. Acta Oecologica 5, 387-394.

Aston, A. R., GiLl, A. M., 1976: Coupled soil moisture, heat and water vapor transfer under simulated fire conditions. Australian Journal of Soil Research 14, 55-56.

BAYRAKLI, F., 1987: Soil and plant analyses (in Turkish). Ondokuz Mayýs University, Samsun. University of Ondokuz Mayis, Faculty of Agriculture Publications, Samsun.

Bilgili, E., Saglam, B., 2003: Fire behavior in maquis fuels in Turkey. Forest Ecology and Management 184, 201-207.

BOYDAK, M., 2004: Silvicultural characteristics and natural regeneration of Pinus brutia Ten. - a review. Plant Ecology 171, 153-163.

Buhk, C., Götzenberger, L., Wesche, K., SÀnchez Gómez, P., Hensen, I., 2006: Post-fire regeneration in a Mediterranean pine forest with historically low fire frequency. Acta Oecologica 30, 288-298.

DAUBENMIRE, R., 1968: Ecology of fire in grasslands. Advances in Ecological Research 5, 209-266. 
DAVIs, P. H. (ed.), 1965-1985: Flora of Turkey and the east Aegean islands. 1-9. Edinburgh University Press, Edinburgh.

Fady, B., Semerci, H., Vendramin, G. G., 2003: Euforgen Technical guidelines for genetic conservation and use for aleppo pine (Pinus halepensis) and brutia pine (Pinus brutia). International Plant Genetic Resources Institute, Rome.

Faraco, A. M., Fernandez, F., Moreno, J. M., 1993: Post-fire vegetation dynamics of pine woodlands and shrublands in the Sierra de Gredos, Spain. In: Trabaud, L., Prodon, R. (eds.), Fire in Mediterranean ecosystems, 101-112. Commission of the European Community, Brussels.

Gezer, A., 1986: The sylviculture of Pinus brutia in Turkey. Options Méditerranéennes CIHEAM 86, 55-66.

HANES, T. L., 1970: Succession after fire in the chaparral of southern California. Ecological Monograph 41, 27-50.

KeELEY, J. E., 1987: Role of fire in seed germination on woody taxa in California chaparral. Ecology 68, 434-443.

Kutiel, P., Shaviv, A., 1989: Effect of simulated forest fire on the availability N and P in Mediterranean soils. Plant Soil 120, 57-63.

Le Houreou, H. N., 1974: Fire and vegetation in the Mediterranean Basin. Proceedings 13 Annual Tall Timbers Fire Ecology Conference, Florida, 237-277.

MAzzoleni, S., Esposito, A., 1993: Vegetative regrowth after fire and cutting of Mediterranean macchia species. In: Trabaud, L., Prodon, R. (eds.), Fire in Mediterranean ecosystems, 87-99. Commission of the European Communities, Brussels.

Mooney, H. A., DunN, E. L., 1970: Convergent evolution of Mediterranean climate evergreen sclerophyll shrubs. Evolution 24, 292-303.

NAVEH, Z., 1975: The evolutionary significance of fire in Mediterranean region. Vegetatio 29, 199-208.

NAVEH, Z., 1990: Fire in the Mediterranean: A landscape ecological perspective. In: Goldammer, J. G., Jenkins, M. J. (eds.), Fire in ecosystem dynamic: Mediterranean and northern perspectives, 1-20. SPB Academic Publishing, The Hague.

Ne'Eman, G., Goubitz, S., Nathan, R., 2004: Reproductive traits of Pinus halepensis in the light of fire - a critical review. Plant Ecology 171, 69-79.

Olsen, S. R., Cole, C. V., Watanabe, F. S., Dean, L. A., 1954: Estimation of available phosphorus in soils by extraction with sodium bicarbonate. United States Department of Agriculture Circular, Washington, D.C.

RAISON, R. J., 1979: Modifications of the soil environment by vegetation fires. with particular reference to nitrogen transformations: a review. Plant Soil 51, 73-108.

SEREZ, M., 1995: Status of forest fires and fire management in Turkey. International Forest Fire News 12, 13-16.

Thanos, C. A., Marcou, S., Christodoulakis, D., Yannitsaros, A., 1989: Early post-fire regeneration in Pinus brutia forest ecosystems of Samos island (Greece). Acta Oecologica 10, 79-94.

Trabaud, L., 2000: Post-fire regeneration of Pinus halepensis forests in the west Mediterranean. In: NE'EMAN, G., TRABAUD, L. (eds.), Ecology, biogeography and management 
of Pinus halepensis and P. brutia ecosystems in the Mediterranean basin, 257-268. Backhuys Publishers. Leiden.

TRABAUD, L., 1973: Experimental study on the effects of prescribed burning on a Quercus coccifera L. garrigue: early results. Proceedings 13 Annual Tall Timbers Fire Ecology Conference, Florida, 97-129.

Trabaud, L., 1987: Dynamics after fire of sclerophyllous plant communities in the Mediterranean basin. Ecologia Mediterranea 13, 25-37.

TRABAUD, L., LEPART, J., 1980: Diversity and stability in garrigue ecosystems after fire. Vegetatio 43, 49-57.

TÜrkmen, N., DüzenLI, A., 1998: The Flora of Dörtyol and Erzin Districts of Hatay Province of Turkey. Turkish Journal of Botany 22, 121-141.

Türkmen, N., DüZENLI, A., 2005: Changes in floristic composition of Quercus coccifera macchia after fire in the Çukurova region (Turkey). Annales Botanici Fennici 42, 453-460.

Verroius, G., Georgiadis, T., 2002: Post-fire vegetation succession: the case of aleppo pine (Pinus halepensis Miller) forests of northern Achaia (Greece). Fresenius Environmental Bulletin 11, 186-193. 